\title{
The Cabinet in the Seventeenth and Eighteenth Centuries
}

THE cabinet when we first meet with it in our history is 1 a group of ministers chosen and dismissed at his pleasure by the king. We know it now as a body of men united in political opinion under a leader by whom, at the king's request, they have been chosen for their respective offices; they are necessarily members of one or other house of parliament; they are the political heads of government departments ; they accept a joint responsibility for their individual and collective action to king and parliament, and they depend for their existence on the support of a majority of the house of commons. Throughout its history the cabinet, with the king, has determined the policy of the country, though the part which the king has played varies from time to time and tends to diminish.

Until comparatively recent times historians accepted the cabinet without endeavouring to account for it, and were inclined to speak of the cabinets of William III or George III much as if they were like one another or like the cabinets of to-day. Lord Morley in his life of Walpole is, I think, the first to call attention to the action of committees of the privy council in the reign of Anne, to the composition of Walpole's cabinets, and to suggest the possible existence of a titular as well as of an efficient cabinet.

Of late years additional light has been thrown on the subject by the Newcastle MSS. in the British Museum, and by research-still far from complete-in the Record Office. We also have in the lives of Lord Granville and Mr. Gladstone some pictures of the working of cabinet government in the reign of Victoria. But it is well to admit that some parts of cabinet history are more obscure than others, and they are just those which affect the changes in the balance of forces in our constitution. The relations of king to cabinet mark the existence and decline of the personal and active influence of the Crown in the initiation of national policy; the supersession of the privy council by the cabinet marks a stage in which criminal responsibility enforceable by impeachment begins to give way to moral responsibility enforceable by loss of office. The gradual disap- 
pearance of the titular as distinct from the efficient cabinet renders possible the development of collective ministerial responsibility, and the association of cabinet rank with departmental rather than courtly duties.

We must also take care not to look for precision of outline and regular sequence of development in an institution so dependent on the conditions of the time and the temperament of individuals. During a large part of the eighteenth century party politics had degenerated into a scramble for office among a set of family groups. To such a state of things it is idle to apply the political notions of to-day. And we must look not only to the conditions of the time, but to the character of the leader who presided over the cabinet of the time. Walpole was not tolerant of opposition among his followers ; Grafton complained that he was outroted in his cabinet; the precarious life of the first Rockingham ministry was ended by the action of its lord chancellor, Northington; but when Thurlow proved obstinately rebellious Pitt demanded and obtained his dismissal.

We must therefore be content to admit that our modern views of party discipline and ministerial responsibility are inapplicable to the conditions of cabinet government, as we now understand it, throughout the greater part of the eighteenth century, nor must we look for sharp outlines in tracing the growth of the institation. Cabinet government is a mode of executive action based on practical convenience. It has developed into a convention of our constitution, but in the course of its development usages grow up, flourish; are outgrown and set aside. Then new conventions form and come to be regarded as the foundations of our public life. The history of the cabinet is a shifting scene in which events move forward with uncertain step but continuous tendency, identifying the cabinet more and more with the public opinion of the time, making it strong if public opinion is strong in its support, weak if that opinion is wavering or hostile. It is a long stage from the junto of Charles II to the cabinet of to-day, from Lord Clarendon to Mr. Asquith, but I would note, at any rate, the earlier stages of transition.

\section{Chardies I and Charlas II}

The term cabinet council was known and used towards the end of the reign of Charles I. It then meant a committee of the privy council. Whether the body described in the History of the Rebellion and the state papers as the 'Lords of the Junto' or ' the Cabinet' was merely a committee for a specified purposeScotch or foreign affairs - or whether it was an inner council to advise the king on all matters is open to question. The king 
may well have consulted on general questions a committee originally intended to deal with a single topic; for the privy council met on fired days, while the junto could be summoned at any time. Clarendon evidently thought that the group which consisted of Laud, Strafford, Cottington, Juxon, the two secretaries, with Northumberland 'for ornament', and Hamilton 'for his skill and interest', was intended to advise the king on all affairs of state.

He may have drawn this conclusion from the character of the junto to which he was himself admitted in the troubled times of 1643.1 This consisted of Richmond, Cottington, Hyde, chancellor of the exchequer, Colepepper, master of the rolls, and the two secretaries. This was a council for all purposes, and when after the Restoration it fell to Clarendon's lot to adapt old forms to new conditions this was the sort of council which he devised.

And so the Treasurer, the Harquis of Ormond, the General (Albemarle) with the two Secretaries of State (Nicholas and Morrice) were of that secret committee with the Chancellor which, under the notion of foreign affairs, was appointed by the king to consult all his affairs before they came to public debate."

Here we have a cabinet, distinct from the privy council and from the committees of the privy council which were formally constituted at the beginning of the reign. ${ }^{3}$ The committee for foreign affairs was set up in 1667 ; in this and succeeding reigns such a committee of the privy council has been regarded as synonymous with the cabinet, but the work of the two can be shown to be distinguishable. This was a consultative body for all purposes, as may be seen from the topics brought before it in Clarendon's time. The sale of Dunkirk might properly come under the head of foreign policy, but not the bill of 1663 for the remoral of the religious disabilities of Roman catholics, nor the scheme propounded by Downing in 1665 for the appropriation of supply.

But this cabinet had no necessary connexion with the house of commons, and, inasmuch as the king was now dependent on parliamentary grant for any money which he needed in excess of the hereditary revenues and the tares settled on him for life, it was necessary to establish some correspondence between his advisers and the lower house. Clarendon proposed to do this by discussions with certain members on whom he thought

1 Life, i 204 ; Crail, Life of Clarendon, i. 231.

- Clerendon, Continuation of Life, i. 370 .

3 The division of the council into committees bad been a Tudor practice; they really served to some extent the purpose and did the work of the modern departments of government. 
that he could rely. Charles was induced to think that Bennet and Coventry could carry on these negotiations better than the friends of Clarendon. Bennet was made secretary in place of Nicholas, who retired on a pension, and Coventry, at the instance of the duke of York whose private secretary he was, also obtained admission to the secret council. Thus was established some relation between the cabinet of Charles III and the house of commons. But we may note in comparison with the modern cabinet that this group of advisers made no pretension to unanimity in public. After Ashley had been admitted into the group he introduced, with the approval of the king, a bill for the relief of the catholics, which was successfully opposed by Clarendon and Southampton; while Clarendon made no secret of his opposition to Downing's plan for the appropriation of revenue which was approved by his colleagues. ${ }^{4}$ Moreover, the decisions of this cabinet ${ }^{5}$ might be pessed on for further and final discussion in the fall privy council, which thus retained its place as a consultative body.

As the reign proceded the recognition of the cabinet as the advisers of the Crown becomes more distinct. Burnet speaks casually of a debate in the cabinet as to what the king should do ander certain conditions; and in the life of Francis North, Lord Guilford, we get a very clear ides of the working of the consultative side of executive government. North, then chief justice, became a member of the privy council as reconstituted on Temple's plan in 1679. He was shortly after admitted to the cabinet in order, as his biographer tells us, 'that he might be an assistant not only in the formal proceedings of the Privy Council but also in the most retired consultations of his Majesty's Government': The development of the cabinet is thus described by Roger North: 'The Cabinet Council which at first was in the nature of a private conversation, came to be a formal Council and had the direction of most transactions of the Government, foreign and domestick.'?

It is noticeable that these cabinets of Charles II, unlike some later cabinets, were composed entirely of persons holding political as distinct from household offices. Lord Guilford has left a note of what he calls ' the Posture of the Cabinet ', when he succeeded Nottingham as keeper of the great seal in 1682 . The members were the lord president of the council, the privy seal, the two secretaries of state, the lord treasurer, the lord-lieutenant of Ireland, and Sidney Godolphin who was a commissioner of the treasury. Plainly the cabinet was a business assembly, made up

- Clarendon, Continuation of Life, iii 15, 16.

- As for instance the sale of Dunkirt (Clarendon, Continuction of Life, ii. 248).

- Roger North, Life of Lord Keeper Gesifford, p. 180.

' Mbid. p. 220. 
of persons whose offices brought them into necessary connexion with affairs of state.

Here, too, as later in Bolingbroke's letters and elsewhere, we see the working of three distinct bodies, the committees of the privy council, the cabinet, and the privy council. North did not attend the foreign committee because he did not feel competent to express an opinion on foreign affairs, but he attended the committee for trade and plantations, "which might be called English business,' and he came into the discussion of foreign affairs by reason of his attendance at the usual councils. The privy council, therefore, discussed reports prepared by its committees, and these may or may not have already undergone consideration by the cabinet. The functions of the privy council were still consultative; some of its meetings were public and were usually held at Hampton Court on Thursdays; but the cabinet met on Sundays, and if the king was at Windsor 'that was always a travelling day for the Lord Keeper', for whom a lodging was provided at the dean's house.

The cabinet of Charles II at the close of his reign was small and businesslike; the great departments of government were there represented, and it contained persons through whom the temper of the house of commons could be ascertained. But the ling determined its composition, presided at its meetings, and could always refer its conclusions for reconsideration to the privy council. Though it was realized that the king's ministers must not fall out with the house of commons, the systematic dependence of the cabinet, as a whole, upon a majority of that house, and the consequent limitation of the king's power to choose his servants is still far off.

\section{WIIIIAM III}

Of the cabinet of Janes II we know little more than that such a body existed; but the reign of William III presents some interesting developments. First it should be noted that the house of commons had acquired a stronger control over the action of the executive, partly by the definition of the powers of the Crown in the Bill of Rights, but mainly owing to the close grip which it now established on finance. These powers were unrestrained by party discipline or any organized expression of public opinion. Government and opposition tellers did not regulate their action, nor did a daily and voluble press influence their tendency. It was diffcolt to secure the continuous support which a ministry requires, nor did the king understand during a considerable part of his reign that this support could only be obtained if he chose his ministers from one of the two great political parties. 
And, moreover, William was not disposed to discuss affairs of state with a body of men some of whom were not in his opinion competent, either by reason of the offices they held or the capacity they might possess, to deal with the matter in hand, and the composition of his cabinets showed that he did not highly regard them for purposes of consultation. Like the Hanoverian kings, he owed his throne to an aristocratic movement, and it is perhaps due to this that he associated the great offices of the household, held by nobles of high rank, with places in his cabinet. We certainly now find the lord chamberlain and the lord steward invested with cabinet rank. We also find places in the cabinet given as matters of compliment to persons not specially qualified by office or ability, bat possessed of sufficient influence to make it desirable that they should be gratified. Sir Edward Seymour was given a place in the cabinet because he was dissatisfied with the precedence which he enjoyed on the treasury commission. ${ }^{8}$ Lord Normanby also received cabinet rank without office, and his position led to an incident which is instructive as to William's views on the subject.

When the king was in Holland in the summer of 1694 Mary was queen regnant; she could only act on the advice of responsible ministers, and it was desirable, as Shrewsbury told the king, 'to get together certain persons to take the lead, otherwise responsibility would rest with one.' On 14 May 1694, Trenchard, secretary of state, summoned a meeting to advise the queen as to some orders to be given in respect to the fleet. Those summoned were Portland, the lord keeper, the lord president, the lord privy seal, the master of the ordnance, and the two secretaries of state. Normanby complained that he was left out. Shrewsbury, who occupied at the moment the chief place in the king's confidence, assured him that this was not a cabinet meeting, but he remained dissatisfied. Shrewsbury reported the matter to the king, saying,

It is certain my Lord Normanby if he be not called will be disobliged to the last degree; and if he should be called, and my lord Steward (Devonshire) and my-lord chamberlain (Dorset) and perhaps some others left out, as certainly they would have the same ground of dissatisfaction.

William's answer shows that he regarded a cabinet council as a formal affair; he says that it was true 'that I did promise my Lord Normanby that when there was a Cabinet Council he should assist at it', but he adds that this did not mean that Normanby should be summoned when it was desired 'to consult on some secret and important affair.' with the great officers of the Crown, whom he specifies as the lord keeper, the lord president, the lord privy seal, and the two secretaries of state. ${ }^{9}$

\footnotetext{
- Lattrell's Diary, ii. 472, 485.

- Shrewosury Corresp. (Core), pp. 34, 38.
} 
Here we have the suggestion of an inner circle for secret and important affairs and a larger one for more ordinary administrative business. William was too impatient of the need of consultation with ministers to carry these ideas into systematic effect; but we have a record of the meetings of the cabinet as understood by William, extending over two years from April 1694 to May $1696 .^{20}$

The number present never exceeded twelve, and the central figares are those above mentioned, whom William described in writing to Shrewsbury as 'distinguished by their office from the other counsellors of state'. But along with these are the lord steward and the lord chamberlain and the archbishop of Canterbury after the appointment of Tenison. In the later meetings the treasury is represented by Godolphin, and in the winter of 1695-6 the admiralty by Russell. When the king was in England he usually presided, and in some of the later records 'the Prince', presumably George of Denmark, appears.

The business transacted is almost entirely of an administrative character and concerning the war; but in the autumn of 1695 the question of the coinage came before the cabinet, and on 16 October it was resolved that they should confer with the lords of the treasury. Some reference is made to these conferences in a letter from Shrewsbury to his colleague Trumbull, of 7 November 1695, and there is a record of a cabinet meeting of 12 November at which two lords of the treasury, Fox and Smith, were present, but the minutes throw little light on what must have been an interesting discussion.

It is noticeable that in these minutes no reference is made to the general policy of ministers or to bills before parliament, and one realizes how different were the cabinets of William III from those of to-day, when their records contain no allusion to the Place Bill, or the Triennial Bill, to the crestion of the Bank of England, or, except in a jejune and passing minute, to the state of the coinage.

There remain three points to note as regards the cabinet in this reign.

The committes of council are referred to from time to time in the Montagu MSS., and it would not be safe to assume that they were not discharging some of the duties which they performed under Charles II ; but we may be pretty sure that William III was not likely to rely much on a foreign committee for the handling of foreign affairs.

The introduction of the archbishop and one or more officers of the household seems to have become a recognized feature of

1- Hist. MSS. Commicrion, Yontagu House Papers, vol. ii, part i. A comparison of theos minutes with the register of the privy conncil shows clearly that they were not records of meetinge of the council. 
cabinet formation. Sunderland in 1700 describes an ideal cabinet, to be formed if the whigs had a majority at the next election." It contains the great officers mentioned by William as proper to be consulted in secret affairs, with the addition of the first lord of the treasury, the archbishop, the chamberlain, and the lordlieutenant; he suggests the first lord of the admiralty and the master of the ordnance as possible additions, and remarks that 'it would be much to the king's service if he brought his affairs to be debated at that Council'. 1s This last reflection does not suggest an inner, secret cabinet, but rather a regret that William kept the initiation of policy to himself, or consulted only such persons as from time to time he might think worthy of his confidence. The making of the first partition treaty illustrates the constitutional difficulties which might arise where the king chose to be his own minister for foreign affairs, and constrained his chancellor and secretary of state to send him the necessary forms for the ratification of a treaty without the collective responsibility of a cabinet.

Lastly, it is plain that the cabinet was gaining power at the expense of the privy council, and that the cabinet under William III was itself liable to be superseded by royal action. This gave rise to debate in the commons, ${ }^{13}$ and resulted in the abortive provision of the Act of Settlement, designed to ensure that executive business should be dealt with in the council, and not elsewhere; and that responsibility should be fixed on those who had consented to what was done. Executive acts had then, as now, to be carried out in certain forms: ministers, who might be impeached for the improper use of these forms, needed some better authority for their use than the king's command; and though the privy council had outgrown its capacity for the transaction of executive business, the authority which it gave to executive action would shield a minister. William was impatient of submitting serious questions of policy to the discussion of any regularly constituted cabinet. Hence his reign marks a decline in the powers of the privy conncil, but does not do much to carry forward the development of cabinet government.

\section{ANNE}

The reign of Anne seems in some respects to take us back to the later years of Charles II. Bolingbroke's description of the working

"Sunderland to Somers, Hardwicke State Papers, ii. 46.

n There is an earnest appeal from Shrembury to the king at the end of 1694 not to issue certain orders to Sir George Rooke, of which Shrewsbury approved, without a previous reference to the cabinet council (Core, Shrecusbury Corresp., p. 78).

13 Parl. Biat. จ. 731, 23 November 1692 The debate is most interesting as showing the uncerteinty which provailed as to where responsibility lay. 
of executive government, as drawn from his letters, is very nuch like that of Roger North. We have the committees of council preparing business, the cabinet considering it, the final stage being reached in the privy council. Yet there is change-in two directions. The queen appoints and dismisses her ministers, and they do not come in or retire in a body like a modern cabinet, but the queen's choice is determined by considerations of party politics and parliamentary majorities. And what is more obvious and striking, the privy council has lost its consultative powers, and never regains them. When the treaties of peace and commerce were laid before the council in $\mathbf{1 7 1 3}$ for their formal ratification, which was proposed by the queen, Lord Cholmondeley asked for a postponement with a view to further consideration. He was informed that the tresties must be ratified at once, and his indiscretion was panished by removal from office. ${ }^{14}$

These functions were resamed for a moment at the meeting of the privy council at which the queen's physicians were consulted, and the queen was advised to confer upon Shrewsbury the treasurer's staff. This was in an emergency. The queen was dying; the chief office in the government was vacant; there was no one to summon the cabinet, at which it was customary that the queen should preside. The action of the privy council was nstural enough, but it was the action of the council, not of the cabinet, as is shown by the Register for $30 \mathrm{July} 1714$.

The work of the committees of the council, and in particular of the foreign committee, needs to be considered. Some have thought that the cabinet grew out of the foreign committee, but the description of their respective functions by Roger North and by Bolingbroke must put an end to any such theory. The references to the cabinet are constant, and to the committee as preparing material for discussion at the cabinet. Thus Bolingbroke writes to Strafford that as the committee of council does not sit till to-morrow, nor the cabinet till Monday, he has only material for a short letter, but on Tuesday, i.e. after the sitting of the cabinet, 'I shall inform you of the Queen's sense in every particular.' 15 And later he writes to the queen, ${ }^{16}$ 'The draft (of the Treaty of Peace and Commerce) will be ready for the Lords of the Council to-morrow, and for your Majesty on Sunday, when I hambly presume you would have the Cabinet sit as usual' 17

Some light may be thrown on the work of these committees

1" Parl. Bir. vi 1170; Swift's Journal, 7 and 8 April 1713.

is Bolingbroke, Letters, ii. 699.

1? Letters, iv. 302 A letter of 20 September 1711 (i. 368) thows the authoritative character of the committoe. They direct the secrotaries of state to confer prith. the representatives of France and bring propositions for their consideration; bat the cabinet conncil is referred to at the end of the letter as a distinot body. 
when, if ever, the history of the departments of government is investigated. Apart from the officers who had the custody of the seals-the lord chancellor, the lord privy seal, and the secretaries of state the only departments were the treasury and the admiralty. The work of the board of trade and plantations was mainly done by the privy council and the secretary of state for the southern department. Practically all other business passed through the hands of the two secretaries of state. The staff of these officers consisted in 1694 of six clerks for the principal secretary and five for his colleague. Each secretary had the appointment of his clerks, so that there was no security for a trained civil service. ${ }^{19}$ Not only were the secretaries unprovided with a skilled staff, but they do not seem even to have enjoyed ordinsry clerical assistance. Bolingbroke apologizes to the queen because, owing to pressure of .work, he had employed a clerk to transcribe certain documents which had to be laid before the queen ${ }^{10}$ instead of writing them out himself. ${ }^{20}$

To each secretary was assigned a separate department of foreign affairs, one dealing with the states of northern, the other of southern Europe. We can well understand that a committee of council might be of great use in bringing our foreign policy under one survey, and in enabling the secretaries to lay their business before the cabinet with facts and precedents prepared for the consideration of their colleagues. The committee, in fact, did something of the work which the staff of the foreign office now does for the secretary of state. But its work was only a preparation of material for the cabinet; we shall come across it at the beginning of the next reign, but never in the constent and important activity shown in the reign of Anne.

\section{The Hayovariavs}

The accesaion of George I is commonly, and not unjustly, regarded as an epoch in cabinet government. Lord Acton says that 'Government by party was established in 1714, by party acting by Cabinet'. This language is somewhat obscure, and embodies a large anticipation of facts. There is a good deal of unreality about party government in the eighteenth century, and if we allow ourselves to talk of the cabinets of George I and George III as though they corresponded to the cabinets of Sir Robert Peel or Mr. Gladstone, we fall into error.

Two points of difference must always be borne in mind.

10 Chamberlayne, The Present State of England, p. 243, a wart of Whitaker's almanec for the year 1694 .

10 Bolingbroke, Letters, i. 368, 20 September 1711.

20 Lord Morley comments on the emount of manual labour done' by Walpole in letter writing and transcription (Walpole, p. 108).

VOL XXI.-WO. CXIII. 
First, a ministry could not exist without a majority in the house of commons, but the house of commons was not representative of public opinion, nor, unless feeling outside became dangerously excited, was it responsive to public opinion. A member was not guided as to his vote by the views of his constituents, and might transfer his allegiance from one party or group to another without much fear of results, unless he was the nominee of some great landowner or boroughmonger, to whose opinion he must defer on pain of losing his seat. Influence of this kind was a potent factor in politics. Scotland returned forty-five members, Cornwall forty-two, and the hostility of the duke of Argyll and Lord Falmouth made serious inroeds on Walpole's majority at the general election of 1741. Later, George III utilized the influence of the Crown in the duchy of Cornwall. The duke of Newcastle devoted the best energies of a long and busy life to the arts of parliamentary management, with the result that he made himself necessary to Walpole; that he insisted on sharing the responsibilities of government with Henry Pelham; and that after Pelham's death his unwillingness to entrust the arcana imperii to any competent leader of the house of commons reduced government for a while to chaos. When George III entered the lists as a parliamentary manager he proved an active and formidable competitor, but Newcastle died in 1768, and George III had to submit to a reduction of his means of acquiring infuence when many offices were abolished and the civil list was re-arranged in $\mathbf{1 7 8 2}$. Though the house of commons remained unreformed for another fifty years, no one henceforward acquired the dominant influence exercised by Newcastle or by George III before 1782. At the same time political issues became more definite and interesting. Cabinet government as based on party government-party as opposed to family groups or king's friends-may be said to begin with the ministry of the younger Pitt.

Secondly, we miss throughout this period a personage who is not only familiar but essential to our present political life-a prime minister. No one, until Pitt took office in 1783, enjoyed a free hand in the formation of a ministry, every change is a matter of accommodation as to who should go and who should remain. Walpole repudiated the title of prime minister. The conflicting elements which made up a ministry after his fall would not have recognized any one man as leader. After Carteret's dismissal Newcastle was unwilling to allow to his brother Henry the right of 'being the first person on all occasions '.21 On Pelham's death the king thought that the cabinet should choose the first minister; ${ }^{22}$ Hardwicke thought otherwise; eventually it was settled that

is Coxe, Pelham, i 20 . * Rosebery, Chatham, p. 339. 
the king should suggest Newcastle to the cabinet, and the cabinet. having been prepared for this beforehand, accepted the suggestion.

The evolution of the prime minister is a matter for separate treatment; it is enough to say that during the greater part of the eighteenth century there seems to have been a doubt whether such a person was necessary at all, and a further doubt as to whether he should be chosen by the party, the cabinet, or the bing. ${ }^{23}$ Here again we find that Pitt's ministry stands out as a landmark. He made up his own cabinet, though the appointment of Thurlow may have been a matter of necessity rather than choice; he obtained at a general election as strong an expression of public opinion in his favour as the constituencies of that day were able to provide, and he acted throughout on a principle which later he put into definite form, that it was ' an absolute necessity in the conduct of affairs of this country that there should be a real and avowed Minister possessing the chief weight in the Council, and the principal place in the confidence of the king. That power must rest in the person generally called First Minister.' 24

If we put together these features of the political history of the eighteenth century-a house of commons irresponsible to public opinion, and managed sometimes by a few great personages; a series of ministries rarely homogeneous or constituted by any one definite leader; a lack of great issues which might stir such public opinion as could express itself under the existing representative system; - we can see at once that the king, as the source of executive power, of office and dignity, might exercise a very strong influence on the composition of cabinets; nor are we likely to find any very definite scheme of cabinet government emerging from this welter of selfish interests and family combinations. Plainly we must receive with caution the precise outline sketched by $\mathbf{M r}$. Temperley of the existence and relations of the so-called conciliabula and the outer cabinet. ${ }^{25}$

The great feature of this period is the retirement of the king from presiding at cabinet meetings. This change was not abrupt ; there is some evidence that George I occasionally was present at a cabinet, ${ }^{26}$ and it is quite certain that the prince of Wales during the king's absence in 1716 habitually presided. The letters of Methuen to Stanhope present a picture of the transaction of business which corresponds very closely to Bolingbroke's description a few year's earlier. Again we find a committee of the lords preparing business ' to be laid before His Royal High-

= Grentille Papers, ii. 500; Grafton Hifmoirs. pp. 30̄̄o, 381; Fitzmaurice, Shelburne, iii 343; Stapylton, Canuing, pp. 203, 208, for other anthorities.

"Stanhope, Pit, iv. 24.

is Arte, xxrii $682,1912$.

s* Coxe, Walpole, p. $70 \mathrm{n}$. 
ness at the Cabinet the next day', while formal matters go to the privy council ${ }^{27}$

It is remarkable that George $I$, having had this experience of presiding at cabinet meetings, did not revive the practice when he came to the throne; perhaps eleven years had been long enough to establish a convention. Henceforward the presence of the king at a cabinet is rare, sometimes disputable, always formal. George II appears to have been present on two occasions when the draft of the speech to be made at the opening of parliament was laid before him. ${ }^{28}$ George III, on 21 June 1779, summoned his cabinet to meet him, not for purposes of consultation, but to hear a speech from him on the state of affairs. $\mathrm{H}_{\theta}$ summoned them again in January $1781,{ }^{30}$ on receipt of dispatches from Russia, and asked them for their opinion one by one, a procedure to which a modern cabinet would certainly have demurred.

It must be admitted that our information as to the cabinets of George $I$ is scanty; but there is doubtless much unexplored material at the Record Office; for the absence of the king from cabinet meetings, besides the undoubted change which it produced in the influence of the king over the framing and execution of national policy, had a further result which is convenient to the historian. When the king was no longer present at the deliberations of his ministers it became necessary that he should be informed of their course and result. Hence the long series of memoranda of persons present and resolutions passed at cabinet meetings, of which the Newcastle MSS. contain numerous specimens and the Record Office probably many more than have hitherto been examined. These memoranda are no doubt the earlier form of the cabinet. letter sent to the king by the prime minister after every meeting of the cabinet. The form is slightly different. In the Newcastle memoranda 'their Lordships are humbly of opinion' that certain things should be done. In the cabinet letter, I believe, the prime minister 'presents his humble duty' to his majesty and proceds with a narrative of matters discussed, conclusions reached, and, though rarely, differences of opinion expressed. This is the only record of what has passed at a modern cabinet, and would seem to be a more confidential document than the Newcastle memoranda or minutes. These appear to have been kept not only for the information of the king, but for the convenience of ministers. On one occasion in 1744 the admiralty complained of orders given by the cabinet. This complaint was

- Dom. Entry Books, p. 267.

$\Rightarrow$ Hardwicke, Lifa ii. 115 ; Herrey, Court of George II, ii 533.

- Bis. MSS. Commisrion, MSS. Various, Vi 256.

- Ibid. 


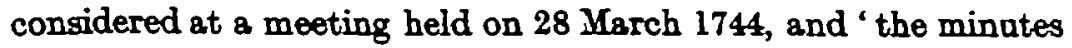
of the Cabinet Council of 2nd February, and the instructions to Sir J. Norris signed by His Majesty in consequence of those Minutes were also read' 31

While we have records of the cabinets of George $I I$ we are met by some problems not easy to solve. First we soon lose sight of the 'Lords of the Committee'. It may be that the departments of government were more effectively manned, and that the lords were not needed to prepare business for the cabinet. More probably, when the hing ceased to preside, the chiefs of departments took more responsibility, and did not need the intervention of these committees to put their business into shape. The absence of the king may have disinclined the lords of the privy council to be at this trouble merely for the benefit of their colleagues who sat in the cabinet. Committes of the privy conncil eristed then, as now, for special purposes; but of the sort of which we read in Roger North's Life, in the Letters of Bolingbroke, and in the correspondence between Methuen and Stanhope, we hear no more.

Then we find developing in the course of the reign a curious distinction between the inner, or 'efficient' cabinet, the conciliabuhum, as it was at one time called, and an outer ring of titular members of the cabinet. In trying to ascertain the nature of this distinction we must bear in mind that it was real and formal, differing in that respect from the dominant influence which it is probable that we should find in every ministry, residing in some two or three of the body.

Bolingbroke defers pronouncing on certain matters until he had conferred with three of his colleagues whom he named. Newcastle called, so he tells us, every morning on Walpole, and afterwards on Pelham, greatly, no doubt, to their annoyance, to discuss and settle the business of the day. In the PittNewcastle ministry much was settled by Pitt, Newcastle, Deronshire, and Hardwicke without reference to their colleagues. 32 George Grenville, with the approval of the king, arranged for weekly dinners at which he, Sandwich, Halifax, and Bedford discussed business informally. It is plain that the younger Pitt, with Dundas and Grenville, kept matters of foreign policy very much in their own hands during the last years of the century. To come to later times, we learn from the life of Lord Clarendon

$n$ Add MS. 33004, fo. 80.

morrens, Birc of Cabivets, ii. 549.

- Grenville Correop. ii. 489. This practioo wes epproved by George III, who mado two suggestions, the first that Grenville should only discass pablic bosiness, and not the eppointments to offices, lest ho should be 'overporvered' by his colleagues; tho otber was that Northington should also be invited, whoee jovial hebits were not conducive to basiness after dinner. This cebinet dinner appears to heve become an institution (Morloy, Walpole, p. 151). 
(ii. 3) that our negotiations with Russia in 1853 were conducted by five ministers, while in the cabinet of 1859 Palmerston and Russell tried to carry out an Italian policy of their own.

But the influence which certain members of a cabinet may exercise over its policy, or the executive action which may be taken by the head of a department after consultation with the prime minister, and perhaps one or two colleagues, without submission to the cabinet, must be dissociated from the position and action of the 'confidential' or 'efficient' cabinet which developed within the larger circle of cabinet ministers. For this efficient cabinet was a recognized group, the ling's pleasure was taken in respect of the persons who composed it, and the results of its deliberations form the subject of memoranda communicated to the king.

An instance of the confusion which may arise from failing to bear this distinction in mind is furnished in Mr. Temperley's article on the Inner and Outer Cabinet in this Roview. In 1737 the king and queen determined to rebuke the prince of Wales for his conduct at the time of his wife's confinement, and to desire him to leave St. James's Palace. Walpole was informed of this, and asked Lord Hervey to draft a letter which he might advise the king to send : the letter was drafted, amended by Walpole, shown to Hardwicke and Newcastle, and approved by the king, who then desired that it should be laid before the whole cabinet 'to make it their act'. When the cabinet met, some, including Newcastle, expressed a wish that the prince should not be turned out of St. James's, and Walpole told them, what was the fact, that the king meant to give the order and that they were only asked to express an opinion as to the form (Hervey, ii. 432). Mr. Temperley uses this story to support a theory of the existence of ' a secret committee or conciliabulum', from the reign of Anne onwards, and of a change in the relations of this committee with the outer cabinet in the time of Walpole. 'Obviously', he says, 'the secret committee is gaining power at the expense of the outer cabinet.' And yet there is nothing in the events recorded which might not happen to-day. The king determines to make a certain communication to a member of his family; he informs the prime minister (if we may anticipate the phraseology), who accepts the responsibility, gets the communication put into shape, consults the lord chancellor and a secretary of state, and then, after the hing has approved the letter, submits it by his wish to the cabinet for consideration of the form. Some of the cabinet object to the purport of the letter. For this the prime minister has accepted responsibility, and the minority who object must give way or regign. If we transpose the facts to the present day, and substitute for Walpole, Hardwicke, and New- 
castle, the names of Mr. Asquith, Lord Haldane, and Sir Edward Grey, we should not be prepared to say that England was governed by a secret committee within the cabinet.

The efficient, inner cabinet is nevertheless a reality which has to be traced and accounted for. I am disposed to date its existence from the Pelham ministry.

We have lists of cabinets and memoranda of cabinet meetings from the latter years of Walpole's ministry, sometimes continuous as in portions of the Newcastle MSS., and scattered through these and other memoirs and letters during the years 1739-70, and from these, and from subsequent references and allusions in parliamentary debate, in correspondence and narrative, we have to build up some general account of the development of cabinet government in the mid-eighteenth century.

Lord Hervey gives us a list of the cabinet in the spring of 1740. It includes seventeen persons, among whom we find the archbishop of Canterbury, the lord steward, the lord chamberlain, the master of the horse, and the groom of the stole. The presence of these household officers makes this cabinet seem a less practical body than the cabinets of the reign of Anne. We may conjecture that George I and his son, like William III, were willing to gratify the great noblemen to whom they owed so much. These might be willing to accept positions which gave them some voice in executive government while they did not involve. the labour of political office. The presence of the archbishop, I confess, is not explained.

A cabinet thus composed lent itself to the formation of an inner circle of men who really did the business of government. In the strong hands of Walpole this business was done without the formal recognition of such a circle. He, with Hardwicke and Newcastle, discnssed and settled policy and carried their conclusions in the miscellaneous body of which the cabinet was composed. There is no evidence in the cabinet memoranda of 1739 and 1740 of an 'efficient cabinet' within the larger body. The numbers vary from six to fifteen, but the personages also vary, and the average number of those present is nine or ten.

In the years following Walpole's retirement, when Pulteney, Carteret, and the Pelhams were struggling for mastery in the cabinet, the formation of a recognized inner circle was obviously onlikely if not impossible. The meetings of 1743-4 were large, sometimes numbering sisteen or seventeen. We may take as a typical cabinet of that period the one in which Carteret's

24 Torrens, $i$ 82, gives a liat of the first cabinet of George I, which inalndes the archbiahop, the oterrard, the chamberiain, and the master of tho horse, Derombiro, Shrombory, and Somerset. Ho unfortmately gives no anthority for his lists of cabinets. 
proposed convention with the queen of Hungary was negatived by eight to four. Argyll, whose presence brought the numbers up to thirteon, was for ratifying with explanations. ${ }^{35}$ We hare few records, after $30 \mathrm{March}$, for 1744 ; in the autumn the numbers dwindled to five or six, but Carteret attended till close on his retirement. ${ }^{36}$

It is not until after this period that we begin to trace the growth of a definite and acknowledged inner cabinet. In September 1748, when Newcastle was with the king in Hanover, dispatches arrived which caused Bedford, the other secretary, 'to desire a meeting of those of his Majesty's servants who are in town.' 37 This is described in a letter from Hardwicke to Newcestle as 'a meeting of such of the Lords as are usually consulted on secret affairs'. It comprised the lord president, the privy seal, the chancellor, Pelham, Bedford, and Grafton, the lord chamberlain. Richmond and Devonshire, master of the horse, and lord steward, would have attended, but they were not in London ${ }^{38}$

Here there is already a distinction between the lords who were and those who were not 'usually consulted on secret affairs'; and though the officers of the household appesr, they were noblemen of political weight and importance. But these characters shortly pass off the stage, and the personal element, which so much affects the history of cabinets, manifests itself. In 1749 Devonshire resigned; Richmond died in the following year; Pembroke and Montagu, groom of the stole and master of the ordnance, died in 1749.

Pelham, writing to Newcastle in August 1750, says,

Death or retreat has taken away all our old friends and fellow-servants, the Duke of Grafton, 30 Lord Chancellor and yourself excepted. In a little while there will be but one man in the Cabinet Conncil with whom we began the world, or carried on business till within these very few years. I own this reflection often strikes me, and makes me greatly fear new experiments. It is extraordinary that three of our own ages, pretty near all old and intimate acquaintances, should die out of that body in less than B year. 4

Perhaps we may reasonably conjecture that the Pelhams, who were alike jeallous of power and afraid of responsibility, took this

2s Add M.8. 3004, fo. 57, 24 November 1743.

add MS. 32993, fo. 278 . Tho langut cabinets were both hald on 2 February 1743/4 when wo note the excoptionil appearance of Marshal Wede and Sir John Norris The oocacion pras the seiling of the French fleot from Brest: Add. MS. 3004, ffl 58, 59.

- Bedford Corresp is 5\%9. "Core, Pelham, ii 317, 319.

20 Tho ling had a strong personel regard for this doke of Grafton: 10 Wabdegrave, Memoirs, p. 114; Grafton, Autobiog a Pp. 10, 11.

- Coxe, Polham, ï. 381. 
opportunity to narrow the circle of confidential advisers of the Crown. Henceforward the group consists of the chancellor, Hardwicke, a tried friend, whose interests were bound up with theirs, a secretary of state of the type of Bedford, an idler, or Holdernese, a nonentity, and Granville, who had come to regard politics as a pastime. When Sandwich was displaced by Anson, the admiralty is represented in the group, and the double object attained of securing the advice of a practical sailor and the accession of a son-in-law of the chancellor.

The officers of the household, such as were present at Walpole's cabinet, seem to have acquiesced, not perhaps unnaturally, in the definite assignment of political business to this inner cabinet. They had no departmental affairs to bring on for discussion, and perhaps no opinion to offer, nor material to form one, on the course of negotiations with foreign powers, or the business of nsval administration. At any rate we find henceforth two kinds of cabinet meetings distinguishable in the Newcastle MSS. One consisting of the chancellor, president, first lords of treasury and admiralty, and the two secretaries of state; the other comprising in addition the archbishop and the household officers. A meeting of this latter kind was held on 6 February 1753 to endorse the communication of a letter dealing with questions between ourselves and Prussia to our representatives in Paris, Vienna, Petersburg, and the Hague. Another was held on 12 March 1754 to consider the king's suggestion that Newcastle should succeed Pelham at the treasury, and that other ministerial changes should be made."

In 1755 the usual attendance at the cabinet consists of the great officers above mentioned, Newcastle, Hardwicke, Granville, Anson, Holdernesse, and Robinson, but from time to time this body are humbly of opinion that certain matters should be 'laid before the Lords of the Cabinet Council', or that 'a general Cabinet Council be summoned' for a particular day." On such occasions the lesser group is afforced by the household officers and others. In December 1754 Fox was admitited to the cabinet while secretary at war ; his name appears at meetings of the general csbinet, but not at those of the inner group until December 1755 , when he became secretary of state."

a To this meoting Dovonshire, who had recigned his housobold offlce five yeare betore, wea summoned by the opecial desire of the king: Add MS. 32995, fo. 60. Tho soquiencenco of the archbishop wes signified by letter.

a 17 and 21 April 1755: Add MS. 32996, ff. 77, 89. $\triangle$ aimilar meeting of tho lerger group is held, though not in consequence of exprese resolution of the inner cabinot, on 10 April, fa. 73. Seo too 15 and 17 March 1756: Add 31S. 32966, II. 377, 378, and leter the larger group is summoned to coenflm the action of the smaller in respeot of a royal mesage ead proclemetion, fi. 419, 423.

- Add MSS. 32995, fo. 374; 32996, if. 321, 357, 375 
A little later the distinction grows more marked. In the negotiations which preceded the formation of the ministry of 1757 Newcastle sketched out plans for cabinets, and of these two contain eighteen and one nineteen persons; but besides these there is a suggested 'Committee of Cabinet to meet upon business'," and this contains ten names including the chief political officers. These were merely suggestions, but they indicate clearly the sort of difference between the confidential and titular cabinets. ${ }^{45}$

But we have the distinction in practice a little later. On 5 November 1761 a cabinet council was summoned for the formal business of receiving the recorder's reports. It consisted of twenty-one persons, including the duke of Leeds, who, as Horace Walpole tells us, had been consoled for his removal from the post of cofferer to that of justice in eyre by being made a cabinet councillor, 'a rank that will soon become indistinct from that of Privy Councillor by growing as numerous.' is But shortly before this, on 2 October, the cabinet meeting which rejected Pitt's proposals for war with Spain is recorded in a letter from Newcastle to Bedford. It consisted of "Granville, lord president ; Devonshire, chamberlain ; Newcastle and Anson, first lords of treasury and admiralty ; Pitt and Bute, secretaries of state; Temple, privy seal; Ligonier $r_{n}$ master of ordnance ; Mansfield, lord chief justice; and Hardwicke. ${ }^{17}$ Here was the efficient as distinct from the titular cabinet, ten persons, all but Deronshire, Hardwicke, and Mansfield holding high political office. There were reasons for including these three men. Devonshire had been first lord of the treasury in the shortlived preceding government, which was not so much superseded as afforced by Newcastle and his friends. Mansfield came in to help Hardwicke with the legal business of the cabinet.

But it is needless to labour the point. The inner cabinet, the 'Cabinet with the circulation of papers', was for many years of the eighteenth century a definite body, the motive force in the political executive, distinguishable on the one hand from any small group who might from strength of will take executive action on themselves or by their influence dominate their colleagues, and on the other hand from the outer group, whose position became more and more formal till it disappears gradually from sight.

4 Add. MS. 32997, if 195, 197, 199, 207.

4 There are similar suggestions with regard to tho ministry of Lord Rockinghem (Add YS. 33001).

4 Add M8. 32999, fo. 332 ; Walpole, Letters, od. Toyabea, r. 36.

- Shelburne, in describing this cobinet, inoludes Henloy, tho lord keoper, and

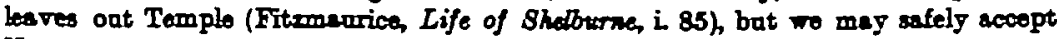
Newcartlo's list (Bedford Corresp. iii. 46). 
We may note some effects of the existence of an inner and outer group. The lack of a sense of joint responsibility in the cabinets of the period had already produced some strange results. Pulteney entered the cabinet, without office, as Lord Bath, after the fall of Walpole. He was never in accord with the Pelhams, but he survived the dismissal of Carteret and attended cabinet meetings until the end of $\mathbf{1 7 4 5}$. When at the beginning of 1746 Pelham, Newcastle, and their friends resigned in order to show the king that no other ministry could command a majority in the house of commons, Bath led a forlorn hope and accepted the first lordship of the treasury. In a few days the king was obliged to recall his late ministers, but they found it necessary to make an express stipulation ' that Lord Bath might be out of the cabinet'. ${ }^{\text {s }}$

And the existence of a double cabinet increased a confusion which already existed as to when a man who had once entered the inner circle ceased to be a cabinet minister. Mansfield became one of the confidential cabinet in 1757 and attended its meetings until the end of the Grenville ministry in 1765. He then asked the king to excuse him from attendance, presumably because he differed from Rockingham and his friends. Nevertheless, he described himself, ten years later, when speaking in the house of lords, as still a cabinet minister, ready to give advice when called upon, but as having, with the king's permission, retired from the 'efficient cabinet'. 40

The variations of responsibility were confusing. The second Lord Hardwicke in 1766 desired to be a member of the Rockingham cabinet without office, but ' with the communication of papers'.so Grafton in 1771 was willing to take office as lord privy seal on the condition that he was not summoned to any cabinet. Lord North writes :

I am not acquainted with your Grace's former opinion respecting the confidential Cabinet, but you will consider that it is not near so numerous now as it was when Lord Bristol was appointed Keeper of the Privy Seal. Your Grace, however, may be assured that the king means to offer you the Privy Seal in the manner most agreesble to you, and I know that I may equally depend on your advice and assistance whether you are nominally of the Cabinet or no.

Previously to this the king had given his commands to Lord Rochford, one of the secretaries of state, to 'keep Grafton

- Coxe, Petham, i 295.

- Parl. Bick Iriil 274, 275, 279 . Tho dake of Richmond stated in this debate thet 'the correpondence with our foreign ministers, at a convenient time, is sent rownd in littlo blue boxes to the efficient cabinet ministers'.

so Rockingham Memoirs, is 330 . In a sketch of a reconstracted cabinot which appears in the Newcestle MSS. 2s 'Plan taken down by Lord Rockingham', Lord Herdwicke and the dake of Richmond are put down as 'called to secret conncil', the first without office, the second as constable of the Tower. 
informed of all business of any importance that was in agitation', 'a distinction', seys Grafton, 'which though honourable to myself, was not without some inconveniences.' s1 It would seem that when Grafton ceased to be first lord of the treasury he was still kept informed of the course of business, and that when he returned to office, though not one of the confidential cabinet, his advice was expected to be given as if he were.

We are indebted to Lord Loughborough for a settlement of the doubts which existed as to the position of the ex-cabinet minister. When Addington succeeded Pitt in 1801, Loughborough, who had been chancellor, was displaced by Eldon; but he chose to assume that he remained a member of the cabinet unless definitely removed, and he appeared, an unwelcome figure, at the first meetings of Addington's cabinet. ${ }^{52}$ Addington's letter to him clears the ground: "His Majesty considered your Lordship's attendance at the Cabinet as having naturally ceased upon the resignation of the seals.' This would establish the connexion of office with attendance at the cabinet; but Addington goes further, and lays down as a rule that 'the number of Cabinet Ministers should not exceed those whose responsible situations in office require their being members of it'. This would seem inconsistent with the existence of the titular cabinet, and yet this last reappears in a shadowy form a few years later, in the grand or honorary cabinet described by Speaker Abbot ${ }^{35}$ as having been held by the king before the opening of parliament to hear the draft of the speech from the throne. This body, which comprised the ministers, the household officers, the archbishop of Canterbury, and the Spesker, corresponds very closely, except in the inclusion of the Speaker, with the cabinets of Walpole described by Lord Hardwicke and Lord Hervey.

We need not look for the abrupt termination of the existence of this outer cabinet; its disappearance was inevitable; it was not noeded to determine policy, for that was settled at the confidential or efficient cabinet; nor did it serve any purpose of executive government, for formal business was transacted at the privy council. The end of it is easier to understand than the beginning. When the inner cabinet began its formal communications to the king of the result of meetings to which the outer cabinet were not summoned, we enter upon a state of things very different. from the discussion of business by an inner group with. results which were accepted as of course by the whole cabinet and then commonicated to the king.

The absence of the king in Hanover would doubtless necessi-

4t Grafton Menoirs, pp. 263-1.

s Cempbell, Lives of tre Chancellors, vi. 326-7; Stenhope, Life of Pith, iii 323.

s Corropondence of Lord Colcheoter, ii. 2 . 
tate the dispatch to him of important communications at a time when the non-political officers might be away from London, and the simultaneous disappearance of some of the most important of these would seem, as I have noted, to have given an opportunity for the Pelhams to create a formal distinction between the two sorts of cabinet ministers.

Then the outer cabinet became a means of paying an inexpensive compliment to a politician whom it was desirable to conciliate; it also enabled George III in his conflict with the whig aristocracy to negotiate behind the backs of ministers with whom he was dissatisfied, and endeavour to bring about fresh combinations with a view to their overthrow. He conld take advantage of the uncertainty which existed as to whether retirement from the confidential cabinet involved loss of place in the outer circle of possible advisers of the Crown.

While the double system lasted it seems incompatible with the collective responsibility of a cabinet. The archbishop of Canterbury and the lord steward would not be prepared to accept responsibility for advice tendered and action taken of which they knew nothing. We must realize, howerer, that our ideas of ministerial responsibility are not those of the politicians of the eighteenth century. That responsibility then, as now, was twofold-to the king and to parliament and the public. Failure in duty to the king might be visited with dismissal, but failure in duty to the public involved a heavier risk, the liability to impeachment. The king might retain advisers who were incapable or unpopular, but so long as they could be identified they could be impeached.

The secrecy of cabinet deliberations, which was a bar to this identification, was one of the original objections to cabinet government; and clearly the criminal liability of the individual minister does not seem at first sight to be compatible either with secrecy of discussion or collective responsibility. Secrecy was on the whole fairly well secured by the privy conncillor's oath, but the collective responsibility of a cabinet was questioned in the debate on Lord Ellenborough's acceptance of a seat in the cabinet in 1806, when lord chief justice, and was impugned even by Fox; ; $^{\text {st }}$ while Hallam, as late as 1827, comments on the difficulty which it interposed to the impeachment of a cabinet minister.

We now consider that lose of place, power, or reputation, is sufficient punishment, and a majority which can secure an impeachment can also turn out a government. We do not desire to se a single member of a government made the scapegoat for shortcomings for which his colleagues should share the responsi-

* Cobbett, Parl, Debatee, vi 308, 311 
bility. Our ancestors thought differently, and this difference must be recognized if we would understand some features of the political life of the eighteenth century.

There are still many obscure places in the history of the cabinet. We know little of its working in the reign of George I or during the first years of George II. Mr. Torrens had evidently explored this period, bat he gives us political bistory, without authorities, when we want to understand the machinery of government.

The history of the departments of government has still to be written; it may throw some light on the working and the disappearance of the committees of the lords of the council which at one time figure so prominently in relation to the cabinet. But since cabinet government developed on the lines which we now recognize during the reigns of the first three Hanoverian kings, and largely during the first two, a period during which neither our system of representation, nor the conditions of political parties helped to bring public opinion to bear on the action of government, we must watch the personal element, the individuslity of kings and ministers, in connexion with the circumstances of the time, or we may be led into framing theories and using phrases about the history of cabinet government which, if not erroneous, are at any rate more precise than the facts will justify.

And we may further take warning by the unnoticed changes which occur almost under our eyes. The increased activity of the state is represented by an increase in the number of departments of government which claim recognition in the cabinet. The increasing mass of departmental work makes it more and more difficult for the cabinet minister to follow the lines of general policy on which a government is conducted; and more and more difficult for the cabinet, as a whole, to follow the policy of any given department. The relations of the cabinet to the committee of imperial defence are as yet undefined. It is enough to mention these festures of cabinet government of to-day in order to suggest caution in framing clean-cut theories about the cabinets of the eighteenth century.

Writam R. Arson.

as [Bince this article was finelly corrected for the Prese, I here read an article contribated by Professor E. R. Turner to tho American $B$ istorical Revieso for Juty and October. I should heve boen glad to comment upon some of tho interesting material which he has collected, but it does not alter the conclusions which I here reached on the subject of Cabinet Dovelopment.-W. R A.] 